\title{
Are we neglecting Earth while conquering space? Effects of aluminized solid rocket fuel combustion on the physiology of a tropical freshwater invertebrate
}

\author{
Rivera-Ingraham Georgina A. 1, 4, ${ }^{*}$, Andrade Madalena ${ }^{2}$, Vigouroux Regis ${ }^{1}$, Solé Montserrat ${ }^{3}$, \\ Brokordt Katherina ${ }^{4,5}$, Lignot Jehan-Hervé ${ }^{6}$, Freitas Rosa ${ }^{2}$
}

${ }^{1}$ Laboratoire Environnement de Petit Saut. Hydreco, Kourou. French Guiana

2 Departmento de Biologia \& CESAM, Universidade de Aveiro, Aveiro. Portugal

3 Instituto de Ciencias Del Mar, Consejo Superior de Investigaciones Científicas (ICM-CSIC), Barcelona.

Spain

${ }^{4}$ Laboratorio de Fisiología y Genética Marina (FIGEMA), Departamento de Acuicultura, Facultad de

Ciencias Del Mar, Universidad Católica Del Norte, Coquimbo. Chile

${ }^{5}$ Centro de Estudios Avanzados en Zonas Áridas (CEAZA), Coquimbo. Chile

6 UMR 9190-MARBEC. Université de Montpellier, CNRS, IRD, Ifremer. Montpellier. France

* Corresponding author : Georgina A. Rivera-Ingraham

\begin{abstract}
:
Space launchers often use aluminized-solid fuel ("propergol") as propellant and its combustion releases tons of $\mathrm{Al} 2 \mathrm{O} 3$ and $\mathrm{HCl}$ that sink in terrestrial and aquatic environments, polluting and decreasing water $\mathrm{pH}$. We studied the impact of these events on the biochemical/physiological performance of the freshwater shrimp Macrobrachium jelskii, with wild specimens collected from a non-impacted site in French Guiana. In the laboratory, shrimps were exposed for one week to: i) undisturbed conditions; ii) Al2O3 exposure (0.5 mg L-1) at normal $\mathrm{pH}(6.6)$; iii) decreased $\mathrm{pH}$ (4.5) (mimicking $\mathrm{HCl}$ release in the environment) with no Al2O3; or iv) Al2O3 $0.5 \mathrm{mg} \mathrm{L}-1$ and $\mathrm{pH} 4.5$, representing the average conditions found in the water bodies around the Ariane 5 launch pad. Results showed that shrimps bioaccumulated Al regardless of water $\mathrm{pH}$. The combined effect of $\mathrm{Al} 2 \mathrm{O} 3$ and low $\mathrm{pH}$ caused the most impact: acetylcholinesterase and carboxylesterase activities decreased, indicating neurotoxicity and reduced detoxification capacity, respectively. Animal respiration was enhanced with $\mathrm{Al} 2 \mathrm{O} 3$ and $\mathrm{pH}$ variations alone, but the synergic interaction of both stressors caused respiration to decrease, suggesting metabolic depression. Oxidative damage followed a similar pattern to respiration rates across conditions, suggesting free radical-mediation in Al toxicity. Antioxidant activities varied among enzymes, with glutathione reductase being the most impacted by $\mathrm{Al} 2 \mathrm{O} 3$ exposure. This study shows the importance of addressing space ports' impact on the environment, setting the bases for selecting the most appropriate biomarkers for future monitoring programs using a widespread and sensitive crustacean in the context of an increasing space-oriented activity across the world.
\end{abstract}




\section{Graphical abstract}

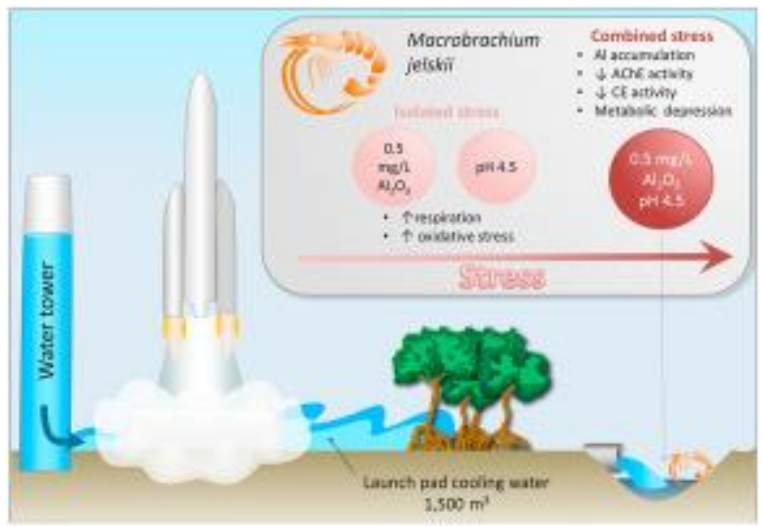

\section{Highlights}

Propergol fuel releases $\mathrm{Al}_{2} \mathrm{O}_{3}$ and hydrochloric acid $(\mathrm{HCl})$ upon combustion. No physiological assessments on their impact have been carried out so far. Simultaneous exposure to these two compounds produces toxicity in tropical shrimps. The impact is mediated by respiration impairment and loss of acid-base regulation. Esterases and glutathione reductase activities are good indicators for this impact.

Keywords : acidification, aluminum oxide, biomarkers, crustaceans, homeostasis, propergol toxicity. 
In the context of space exploration, there is an increasing activity of space ports throughout the world. In 2017, the most active space ports were Cape Canaveral (USA), Kourou (French Guiana) and Baïkonour (Russia) in that order (Bousquet, 2017), counting with 5, 3 and 5 active launch pads, respectively. There are another 8 other important space ports located in the USA, Russia, China, India, Japan and New Zealand, but there are numerous and smaller other facilities worldwide. Though having certainly a limited spatial impact, the environmental pollution caused by such activities, and including in the context of global climate change, calls for the urgent need to determine its consequences on nearby environments and human populations, the final goal being to better assess policy options.

Most commonly, launchers use aluminized solid propellant, known as "propergol", which is composed of about $68 \%$ of ammonium perchlorate $\left(\mathrm{NH}_{4} \mathrm{ClO}_{4}\right), 18 \%$ aluminum (Al) and $14 \%$ de polybutadiene. After each launch, a large (contrail) cloud resulting from the combustion of propergol during the flight is released over several $\mathrm{km}^{3}$ into the atmosphere, and combustion compounds deposit into soils and water bodies (Cencetti et al., 2007; Voigt et al., 2016). For the specific case of Ariane 5, this cloud has been estimated to contain $149 \mathrm{Tn}$ of $\mathrm{Al}_{2} \mathrm{O}_{3}$ (resulting from the combustion of the highly reactive Al particles) (Gonçalves de Miranda, 2000), $120 \mathrm{Tn}$ of $\mathrm{CO}$ and $\mathrm{CO}_{2}$ and $90 \mathrm{Tn}$ of $\mathrm{HCl}$ (De Lacour, 2011). But the launch pad itself is left with most of the pollutants, which derive from the acid (ground) cloud produced during the take-off (Richard and Chemoul, 2012). This is composed of unneglectable accumulations of $\mathrm{Al}_{2} \mathrm{O}_{3}$ microparticles and $\mathrm{HCl}$, which reach nearby aquatic compartments when over $1,500 \mathrm{~m}^{3}$ of water are released on the launch pad surface to cool down ground installations (Harvey, 2003). For the case of Kourou's Space Port, this cloud has been estimated to most significantly pollute the $1 \mathrm{~km}^{2}$ around the launch pad and to affect an area of up to $8 \mathrm{~km}^{2}$ (De Lacour, 2011) and its particles have been detected at least several weeks after a launch (Vigouroux, pers. 
obs). Even if up to date the quality of the freshwater bodies located roughly around space ports has been monitored from a physico-chemical perspective, to the authors knowledge there are no studies addressing the impact of these launches on the fitness and physiology of the macrofauna present around the launch pads and connecting waters.

Even if certain molecules released from the combustion of propergol may be degraded or become biologically unavailable, others may have an important ecotoxicological impact and interfere with physiological processes in the short, medium and long terms. Among these, $\mathrm{Al}_{2} \mathrm{O}_{3}$ particles stand out, and upon combustion these reach the environment in the micro-size range (with a size of 3-4 $\mu \mathrm{m}$ for the smallest particles and up to $50-60 \mu \mathrm{m}$ for particle agglomerates) (Gonçalves de Miranda, 2000). In general terms, aluminum-based compounds are of particular interest given that, as far as it is known, this element has no physiological role (reviewed by Nayak, 2002). It is often responsible for adverse physiological effects to humans: it is a known neurotoxic agent (Kaizer et al., 2008) and is believed to be responsible for neurodegenerative diseases (Halatek et al., 2005). Aluminum has also been long recognized to be a toxicant for aquatic species, particularly in gill breathing fauna. Gills are osmoregulatory organs, and Al may accumulate in its tissues and compromise the activity of enzymes involved in ion uptake, leading to loss of plasma/haemolymph ions and eventually causing osmoregulatory failure (Rosseland et al., 1990). Aluminum toxicity could be accentuated when environmental $\mathrm{pH}$ is reduced, as happens around the launch pads due to the concomitant release of $\mathrm{HCl}$. In such cases, aquatic fauna is increasingly impacted, because: i) low $\mathrm{pH}$ increases the solubility of $\mathrm{Al}$ in water (e.g. Rejeki, 2003); ii) a decrease in $\mathrm{pH}$ in the environment may cause metals to enter tissues in an ionic state, having higher toxic effects than if these compounds remained in a neutral state (Rendal et al., 2011) and iii) because gills, already impacted by Al bioaccumulation, could be increasingly solicited in ion pumping to maintain intracellular acid-base homeostasis (Henry and Wheatly, 1992). 
In this context, there is thus an urgent need to characterize the effect of the generated wastewaters (with $\mathrm{Al}_{2} \mathrm{O}_{3}$ microparticles and with a low $\mathrm{pH}$ ) that infiltrate the nearby sediments and which may enter the freshwater network, especially in the context of increasing activity of space ports. To our knowledge, this is the first study addressing the impact of $\mathrm{Al}_{2} \mathrm{O}_{3}$ microparticles under acidic conditions in the aquatic environment. This is a relatively insoluble compound when compared with other Al-based molecules, which have been extensively used in the literature to address the interacting effects of $\mathrm{Al}$ and low $\mathrm{pH}$ in temperate fish and invertebrates. Nevertheless the information on tropical species remains scarce (Rejeki, 2003). Because space ports are located in tropical and subtropical regions of the world, to minimize the amount of fuel required for launchers to reach space, this work aims to fill in the gap of knowledge on the consequences of these activities on tropical environments. We addressed this issue using a crustacean species because they are known to be especially sensitive to low $\mathrm{pH}$ and Al pollution (Herrmann, 2001). We selected the freshwater shrimp Macrobrachium jelskii (Miers, 1877) Chace and Holthuis, 1948 (Caridea, Palaemonidae) as a model species. This species inhabits the roots and vegetation of margin freshwater environments of the Atlantic coast of Central and South America, roughly from Costa Rica to Argentina (see Collins, 2000 and references therein). The relevance of this model relies on it being of ecological and economical importance, used in fishing, fishkeeping and food (Vera-Silva et al., 2017). It may also potentially become an interesting bioindicator, because Macrobrachium is the largest genus of the family Palaemonidae and that Macrobrachium species are present in waters of every continent except Europe (Holthuis and $\mathrm{Ng}$, 2009). Using this freshwater shrimp, the present study focused on the consequences of launching activities on animal physiological and biochemical performance, given that these key endpoints have been rarely considered, further justifying the interest of this work. Furthermore, most previous studies have addressed Al toxicity using soluble aluminum compounds. Given that the $\mathrm{Al}_{2} \mathrm{O}_{3}$ resulting from the propergol combustion is sparingly soluble at circumneutral $\mathrm{pH}$, the need to characterize its impact on 
113 animal physiology is further required. For the case of $\mathrm{Al}_{2} \mathrm{O}_{3}$ nanoparticles, a previous study using the freshwater branchiopod Ceriodaphnia dubia suggests that its toxicity is due to free radical formation, but also to a perturbation of the energy budget of the cells (Li et al., 2011). Hence, for the first time in an invertebrate species, we address in the present study the effects of $\mathrm{pH}$ on $\mathrm{Al}_{2} \mathrm{O}_{3}$ toxicity from an energy-redox perspective. We focused, on the one hand, on energy use, because all cellular processes (even at basal conditions but especially under environmental changes) have an energetic cost. On the other hand, we analyzed redox balance as the equilibrium between antioxidant defenses and oxidative damage. This is because mitochondria, in their role of cell energy suppliers, consume $\mathrm{O}_{2}$ and consequently produce free radicals (reactive oxygen and nitrogen species) (RONS) which need to be neutralized by (energy-costly) antioxidant defenses. When antioxidant and other detoxification mechanisms are overwhelmed by these compounds, cell structures such as membrane, proteins or DNA may be damaged and eventually induce mutations and cell death.

The present study was conducted in French Guiana, hosting the Guiana Space Centre (CSG) which was here selected as a study case. It is from CSG that most of the European and allied satellites are launched. It covers an area of about $700 \mathrm{~km}^{2}$ and it is composed of three active launch pads for Ariane 5, Vega and Soyouz rockets, with the first two using propergol as propellant. Using M. jelskii, which is commonly found in the water courses around CSG, the final goal of the study is to infer on the physiological and biochemical effects of the combined effects of $\mathrm{Al}_{2} \mathrm{O}_{3}$ microparticles and decreased $\mathrm{pH}$ on this representative crustacean species of the freshwater macrofauna of French Guiana. Ultimately, this study aims to identify suitable early warning biomarkers of launchers' impact in a worldwide represented family of crustaceans to better aid policy managers and advisors in the management of increasing numbers of launch activities worldwide.

\section{MATERIALS AND METHODS}


139

140

141

A total of 150 Macrobrachium jelskii juveniles were collected from Bois Diable Lake

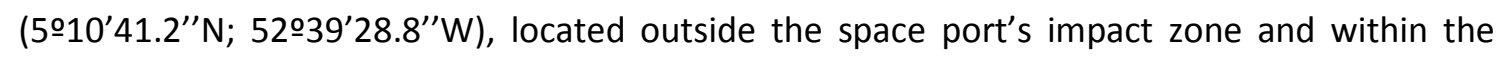
outskirts of Kourou, French Guiana. Care was taken to use animals of similar weight $(0.45 \pm$ $0.03 \mathrm{~g}$ ). Water parameters at the collection site were the following: $92 \%$ air saturation (WTW Oxi 3205), $0.0 \mathrm{ppt}$ salinity, $213 \mu \mathrm{S} \mathrm{cm}^{-1}$ conductivity (WTW ProfiLine Cond 3110), $30.3{ }^{\circ} \mathrm{C}$ temperature and a pH of 6.6 (WTW ProfiLine $\mathrm{pH}$ 1970i). Water samples were collected at the site for Al content determinations.

Animals were immediately transported to the laboratory facilities at Hydreco-Guyane, where they were maintained in aquaria equipped with aeration systems and maintained with fresh water from the collection site. Animals were allowed to acclimate to laboratory conditions for 5 days. Water was changed each $48 \mathrm{~h}$ using freshly collected water from Bois Diable Lake and $\mathrm{Al}_{2} \mathrm{O}_{3}$ and $\mathrm{pH}$ were reconstituted accordingly.

\subsection{Experimental design}

After the acclimation period, animals were exposed to one of the following conditions: i) unaltered conditions (for control purposes); ii) $\mathrm{Al}_{2} \mathrm{O}_{3}$ microparticle exposure $\left(0.5 \mathrm{mg} \mathrm{L}^{-1}\right)$ at natural pH (6.6) (serving as an $\mathrm{Al}_{2} \mathrm{O}_{3}$ control), iii) decreased $\mathrm{pH}$ (4.5) (serving as a decreased $\mathrm{pH}$ control) and iv) $\mathrm{Al}_{2} \mathrm{O}_{3}$ microparticle exposure $\left(0.5 \mathrm{mg} \mathrm{L}^{-1}\right)$ under low $\mathrm{pH}$ (4.5). The later represents the average $\mathrm{Al}_{2} \mathrm{O}_{3}$ concentrations and $\mathrm{pH}$ values found in the Karouabo stream (where the $1,500 \mathrm{~m}^{3}$ of cooling water ends up pouring) around 7 days after an Ariane 5 launch (Monchaux et al., 2015; Clavier et al., 2017). This particular stream has little exchange rates (especially during dry season), ensuring that our laboratory conditions reasonably mimic those found in the environment. All treatments were carried out in water freshly obtained from the animal collection site. $\mathrm{Al}_{2} \mathrm{O}_{3}$ was purchased from Sigma (purity 99.9\%). This compound is sparingly hydro-soluble at $\mathrm{pH} 6.6$ but its solubility increases under the acidified conditions here 
used. Despite the degree of solubility, the particles were maintained in suspension through the effect of the aquaria aeration systems. In each case, $\mathrm{pH}$ was achieved by the addition of $\mathrm{HCl}$ since it is a major component of the propergol combustion. Three aquaria were used per condition, each containing $5 \mathrm{~L}$ of freshwater (changed each $48 \mathrm{~h}$ ) and 10 animals, making a total of 30 shrimps per conditions. Total exposure time was 7 days. After this period, 6 shrimps per condition ( 2 per aquarium) were used to carry out respirometric analyses and were later preserved in liquid nitrogen to determine $\mathrm{Al}_{2} \mathrm{O}_{3}$ bioaccumulation in tissues. Another 21 animals per condition ( 7 per aquarium) were sacrificed through immersion in liquid nitrogen for biochemical determinations (see below). The 3 remaining animals per condition were fixed in Bouin's fixative for further histological analyses in the frame of another study.

\subsection{Respirometric analyses}

To quantify respiration rates (RR), 10-ml glass metabolic chambers previously equipped with an oxygen sensor spots (OXSP5, sensor code SD7-541-207, Pyro-Science GmbH, Aachem, Germany) glued to the inner side of the chamber were used. For each measurement, a single animal was introduced in the chamber, containing $10 \mathrm{~mL}$ of freshly-prepared medium at the $\mathrm{pH}$ and $\mathrm{Al}_{2} \mathrm{O}_{3}$ conditions to which the animal was exposed during the experiment. Chambers were then closed, ensuring the absence of any air bubbles within the chamber and measurements were carried out at room temperature $\left(25^{\circ} \mathrm{C}\right)$ using a four-channel fiber optic oxygen meter (Firesting, Pyro-Science $\mathrm{GmbH}$ ). All measurements started in fully oxygenated water and oxygen concentration was registered each $5 \mathrm{sec}$ through the Pyro Oxygen Logger software as a functioning of declining $\mathrm{O}_{2}$ partial pressure $\left(\mathrm{pO}_{2}\right)$. Four measurements were recorded in parallel, in all cases 1 being a blank (containing no animals and serving for determining background (microbial) respiration). When possible, animals were allowed to breathe until oxygen was completely consumed in the chamber to estimate the respiratory behavior of these organisms and how water conditions affected hypoxia tolerance. The critical 

$p \mathrm{O}_{2}\left(p_{c} \mathrm{O}_{2}\right)$, as defined by Tang (1933) and indicating the onset of anaerobic metabolism, was calculated using the equation by Duggleby (1984).

After each measurement, all animals within the chamber were weighed and preserved in liquid nitrogen for further quantification of $\mathrm{Al}$ accumulation ( $\mathrm{n}=6$ per condition). RR results were expressed as $\mathrm{nmol} \mathrm{O}_{2} \mathrm{~min}^{-1} \cdot \mathrm{g}^{-1}$ fresh weight (FW).

\subsection{Metal content}

194

Aluminum bioaccumulation in whole soft tissues was assessed for each condition. All 6 animals per condition preserved for this purpose were pooled into a single sample (with two technical samples per pool). Total Al concentrations were quantified by inductively coupled plasma mass spectrometry (ICP-MS, X-Series, Thermo Scientific), after microwave assisted acid digestion. After freeze-drying, 100-200 mg of the samples were digested in a CEM MARS 5 microwave, with $1 \mathrm{~mL} \mathrm{HNO}{ }_{3} 65 \%, 2 \mathrm{~mL} \mathrm{H} \mathrm{O}_{2} 30 \%$ and $1 \mathrm{~mL} \mathrm{H} \mathrm{H}_{2}$, by increasing temperature to $180{ }^{\circ} \mathrm{C}$ in 10 min, which was then maintained for $10 \mathrm{~min}$. After cooling, the obtained digests were transferred into $25 \mathrm{~mL}$ polyethylene vessels and the volume made up with ultrapure water. Quality control was made through the use of blanks, certified reference material NIST 2976 (Mussel Tissue) and duplicates. Blanks were below the quantification limits for Al, the coefficient of variation of samples duplicates was $18 \%$ and mean percentage of recovery was $128 \%$.

Dissolved aluminum in the water from the collection site $(n=4)$ was also determined using inductively coupled plasma optical emission spectrometry (ICP-OES, iCAP 7400 Duo, Thermo Scientific) according to the NF EN ISO 11885 method.

\subsection{Biochemical analyses}

All biochemical analyses were conducted on 4 pools per experimental condition, each composed of 5 animals (i.e. 20 randomly selected animals out of the 21 preserved for this 
212

213

214

215

216

217

218

219

220

221

222

224

225

226

227

228

229

230

231

232

233

234

235

236

237

purpose). Animals were homogenized using a manual potter and liquid nitrogen. Each resulting homogenate was separated into three subsamples of about $0.2 \mathrm{~g}$ of grounded tissue each. One subsample was diluted in a $50 \mathrm{mM}$ phosphate buffer $(\mathrm{pH} 7.0$ with $1 \mathrm{mM}$ ethylene diamine tetraacetic acid tetrasodium salt hydrate, $1 \%(\mathrm{v} / \mathrm{v})$ Triton X-100 and $1 \mathrm{mM}$ dithiothreitol) and was used to assess: i) energy reserves (glycogen (GLY) and protein (PROT) contents); ii) antioxidant enzyme activities; iii) cellular damage (protein carbonyl content (PC)); iv) neurotoxicity and metabolism (acetylcholinesterase (AChE) and carboxylesterase (CE) activities). A second subsample was diluted at a $1: 2$ ratio ( $w: v)$ in a $0.1 \mathrm{M}$ Tris- $\mathrm{HCl}$ buffer (containing 15\% (w/v) PVP, $153 \mathrm{mM}$ magnesium sulfate $\left(\mathrm{MgSO}_{4}\right)$ and 0.2\% (v/v) Triton X-100) and served to quantify electron transport chain (ETC) activity. The third and last subsample was diluted in $20 \%(\mathrm{v} / \mathrm{v})$ trichloroacetic solution and was used to quantify lipid peroxidation (LPO), also indicative of oxidative damage.

GLY content was assessed using the protocol described by Dubois et al. (1956) and using glucose to build the standard curve, which ranged from 0 to $2 \mathrm{mg}$ per $\mathrm{mL}$. Protein content was assessed following the Lowry et al. (1951) method, with bovine serum albumin as standard $\left(100 \mu \mathrm{g} \mathrm{m}^{-1}\right)$. In both cases, measurements were carried out spectrophotometrically at 492 and $750 \mathrm{~nm}$ for GLY and PROT content, respectively. Results were expressed in mg per g FW.

Antioxidant and biotransformation/detoxification capacity of shrimps was assessed through the quantification of the activity 5 different enzymes: superoxide dismutase (SOD), catalase (CAT), glutathione peroxidase (GPx), glutathione S-transferases (GSTs) and glutathione reductase (GR). SOD activity was determined in samples following the protocol original described by Beauchamp and Fridovich (1971). Data were obtained using a curve of SOD standards which ranged between 0.25 to 60 units $(U) \mathrm{mL}^{-1}$, where one $\mathrm{U}$ corresponds to the amount of enzyme causing a $50 \%$ inhibition of nitroblue tetrazolium reduction under assay conditions. CAT activity was measured spectrophotometrically at $540 \mathrm{~nm}$ according to 

$\mu \mathrm{M}$. CAT activity was expressed as $U$ per g FW, where one $U$ of enzyme activity corresponds to the formation of $1 \mathrm{nmol}$ of formaldehyde per min under assay conditions. GPx was determined spectrophotometrically at $340 \mathrm{~nm}\left(\varepsilon=6.22 \mathrm{nM}^{-1} \mathrm{~cm}^{-1}\right)$ (Paglia and Valentine, 1967) and results were expressed as $U$ per $\mathrm{g} F W\left(U=n m o l ~ \min ^{-1}\right)$, where $U$ represent the number of enzymes that caused the formation of $1.0 \mu \mathrm{mol}$ nicotinamide adenine dinucleotide phosphate (NADPH) per min. GSTs were also quantified spectrophotometrically $\left(340 \mathrm{~nm}, \varepsilon=9.6 \mathrm{mM}^{-1}\right.$ $\mathrm{cm}^{-1}$ ) using a method adapted from Habig et al. (1974). Results were expressed as U of GSTs activity per g FW, where one $U$ corresponds to the quantity of GSTs that catalyzes the conversion of $1 \mu \mathrm{mol}$ of 1-chloro-2,4-dinitrobenzene per min. GR activity was measured as the oxidation of NADPH following the protocol described by Carlberg and Mannervik (1985). Measurements were carried out spectrophotometrically at $340 \mathrm{~nm}\left(\varepsilon=6.22 \mathrm{mM}^{-1} \mathrm{~cm}^{-1}\right)$ and expressed as $U$ per $\mathrm{g} \mathrm{FW}$, were $\mathrm{U}$ in this case represents the $\mu \mathrm{mol}$ of $\mathrm{NADPH}$ oxidized per min.

251 Oxidative damage was assessed through the quantification of protein carbonyls (PC) and peroxidized lipid (LPO) content. PC levels were determined using the DNPH alkaline method (Mesquita et al., 2014), results were read at an absorbance of $459 \mathrm{~nm}$ and expressed as nmol of protein carbonyl groups formed per gFW. LPO was determined as TBARS (thiobarbituric acid reactive substances) content using the protocol described by Buege and Aust (1978). Briefly, this method consists in adding 2-thiobarbituric acid (TBA), which reacts with lipid peroxidation by-products (such as malondialdehyde). The resulting TBARS were quantified by absorbance at $532 \mathrm{~nm}$ and results were expressed in nmol of MDA equivalents per gFW.

ETC activity was assessed using the protocol by Packard (1974) with the modifications described by De Coen and Janssen (1997). The absorbance was read at $490 \mathrm{~nm}$ during $10 \mathrm{~min}$ at $25 \mathrm{sec}$ intervals using a microplate reader. ETC (i.e Q-cytochrome B complex) activity was 
262

263

264

265

266

267

calculated as the amount of formazan formed in each well and the results expressed in nmol . $\min ^{-1}$ per g FW.

Neurotoxicity and detoxification capacities were assessed through the quantification of AChE and CEs activities, respectively. For AChE activity determinations we followed the method of Ellman et al. (1961) and modifications by Mennillo et al. (2017). Enzyme activities, measured as the formation of dianion of 5-thio-2-nitrobenzoic acid, were recorded spectrophotometrically for $5 \mathrm{~min}$ at $412 \mathrm{~nm}$ and expressed in $\mathrm{nmol}$ per min per g FW, using the molar extinction coefficient $(\varepsilon) 13,600 \mathrm{nM}^{-1} \mathrm{~cm}^{-1}$. CEs were measured using 2 different commercial substrates: $\rho$-nitrophenyl acetate ( $\rho N P A)$ and $\rho$-nitrophenyl butyrate ( $\rho N P B)$. Activity was measured spectrophotometrically at $405 \mathrm{~nm}$ as the formation of $\rho$-nitrophenol from $\rho$ NPA and $\rho$ NPB as described by Hosokawa and Satoh (2005). Activities were expressed nmol min $^{-1}$ per g FW.

\subsection{Stastistical analyses}

All data sets were tested for normality (Kolmogorov-Smirnov test) and homocedasticity (Levene test). When the assumptions for parametric statistics were met, one-way ANOVA tests were carried out, followed by a Student-Newman-Keuls a-posteriori multiple comparison test. For the rest of the cases, a Kruskal-Wallis test was performed followed by U-Mann Whitney pairwise comparison tests. All these analyses were carried out using SPSS 15.0 (SPSS Inc., IL, USA). All data and figures are expressed as mean \pm standard error of mean (SEM). Significant differences among conditions were represented with different lower and upper case letters in the graphs.

\section{RESULTS}

No mortality was recorded throughout the experiment, suggesting no acute toxicity.

\subsection{Aluminum content in water and bioaccumulation levels}




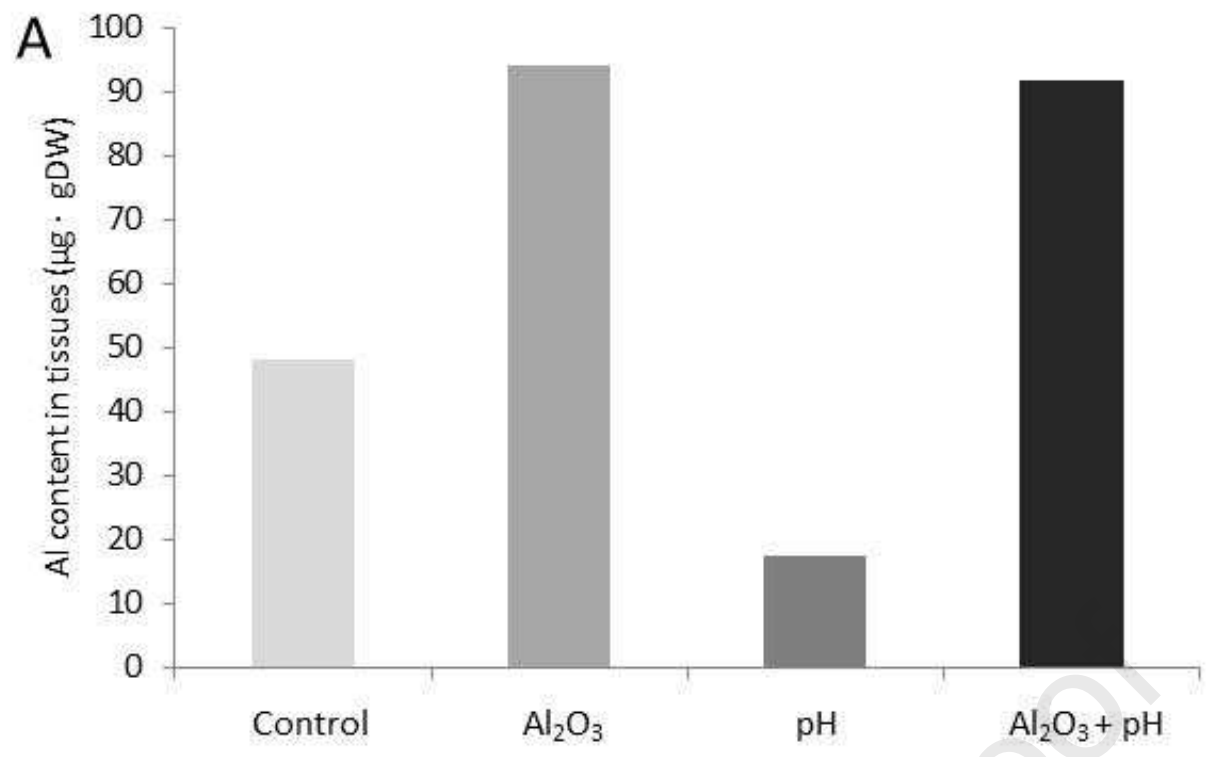

Water at Bois Diable Lake, which was here used for the in-vitro experimentation, showed values below $0.05 \mathrm{mg} \mathrm{Al}$ per ml. Animals exposed for $7 \mathrm{~d}$ to the treatment containing $\mathrm{Al}_{2} \mathrm{O}_{3}$ microparticles in the water (under normal pH) showed Al contents in their tissues that were 2fold higher than the controls (Figure 1). These values were similar to those registered in animals exposed to the combined effect of $\mathrm{Al}_{2} \mathrm{O}_{3}$ microparticles and decreased $\mathrm{pH}$. Animals exposed to acidic water conditions (with no $\mathrm{Al}_{2} \mathrm{O}_{3}$ addition) showed half the content of the control animals.

\subsection{Energy related parameters}

Whole animal respiration rates (RR) were higher in those exposed to high $\mathrm{Al}_{2} \mathrm{O}_{3}$ concentration or low $\mathrm{pH}$ conditions respect to the control $(\mathrm{F}=10.011 ; p<0.001)$ (Figure $2 \mathrm{~A})$. In contrast, animals exposed to the combination of $\mathrm{Al}_{2} \mathrm{O}_{3}$ plus low $\mathrm{pH}$ showed the lowest $\mathrm{RR}$ values. The $p_{c} \mathrm{O}_{2}$ values roughly followed the RR pattern, but differences were not statistically significant among treatments $(\mathrm{F}=1.418 ; p=0.263)$. 

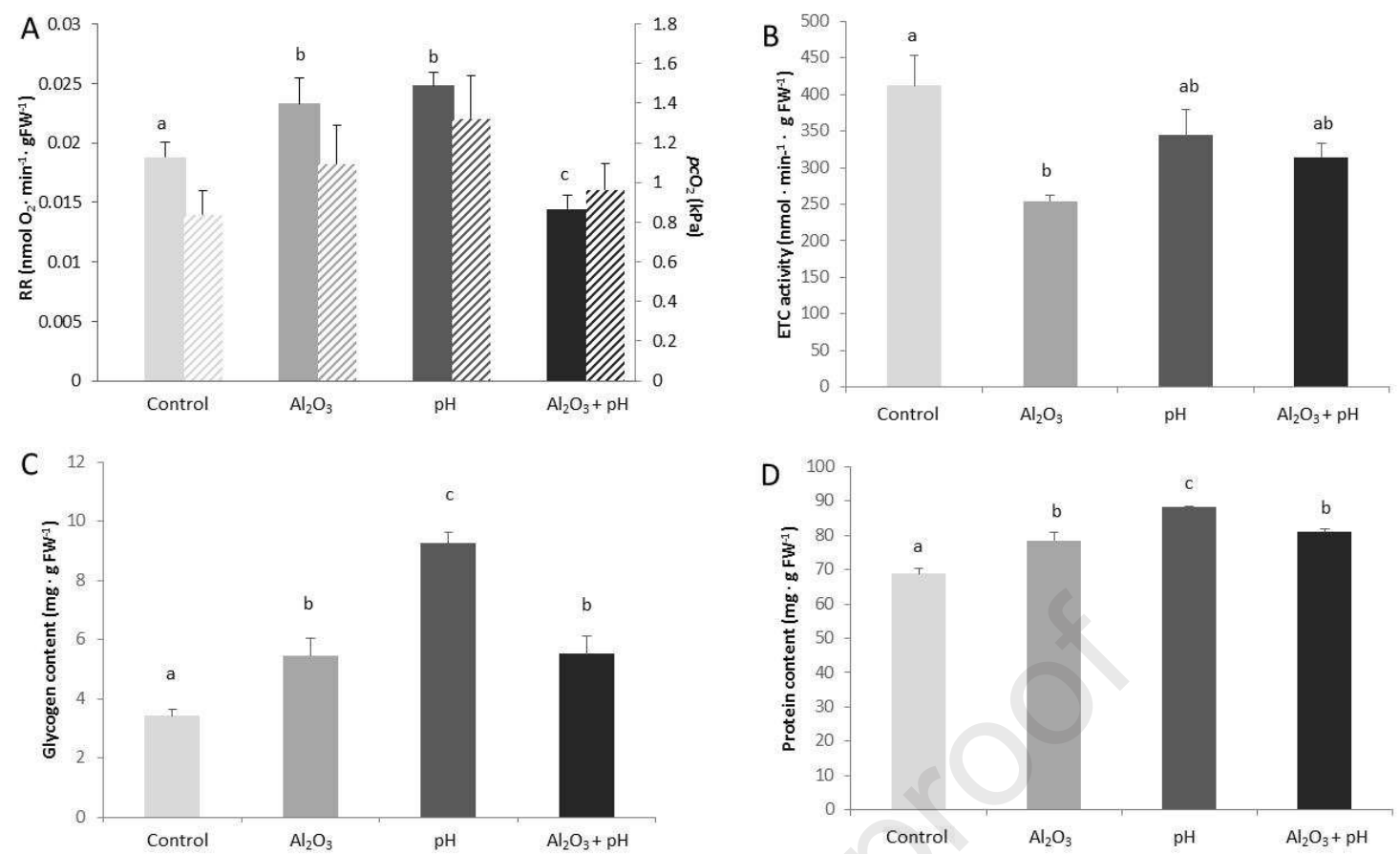

Figure 2: Energetic parameters (means \pm SEM) measured in $M$. jelskii under the different treatments. A)

Respiration rates (RR) and critical $\mathrm{pO}_{2}\left(p_{c} \mathrm{O}_{2}\right)$, shown in plain-colored and striped columns, respectively $\left.(\mathrm{n}=6) ; \mathrm{B}\right)$ Mitochondrial electron transport chain (ETC) activity; C) Glycogen (GLY) content; D) Protein (PROT) content. Values associated to different letters are statistically different from each other, according to a one-way ANOVA test followed by a Student-Newman-Keuls a-posteriori multiple comparison test (for results shown in subpanels A and C), and a Kruskal-Wallis followed by U-Mann Whitney pair-wise comparisons (for results shown in subpanel B and D).

The maximum ETC activity was shown by control animals, while $\mathrm{Al}_{2} \mathrm{O}_{3}$ alone induced a 1.6-fold

decrease. However, overall ETC activities did not match the RR results (Figure 2B). The only significant difference was registered between controls and animals exposed to $\mathrm{Al}_{2} \mathrm{O}_{3}$ under normal $\mathrm{pH}(\mathrm{F}=4.132 ; p=0.038)$.

Both GLY and PROT content were significantly affected by changes in water conditions (GLY: $\mathrm{F}=26.048 ; p<0.001$. PROT: $\mathrm{K}=10.072 ; p=0.018$ ) (Figures $2 \mathrm{C}$ and $2 \mathrm{D}$ ). In both cases data showed a similar pattern: the presence of $\mathrm{Al}_{2} \mathrm{O}_{3}$ in the water (with or without decreased $\mathrm{pH}$ ) caused an increase in GLY and PROT contents by about 1.6- and 1.2-fold, respectively. Animals subjected to a decrease in $\mathrm{pH}$ showed the highest values (2.7- and 1.3-fold over control animals for GLY and PROT contents, respectively). 

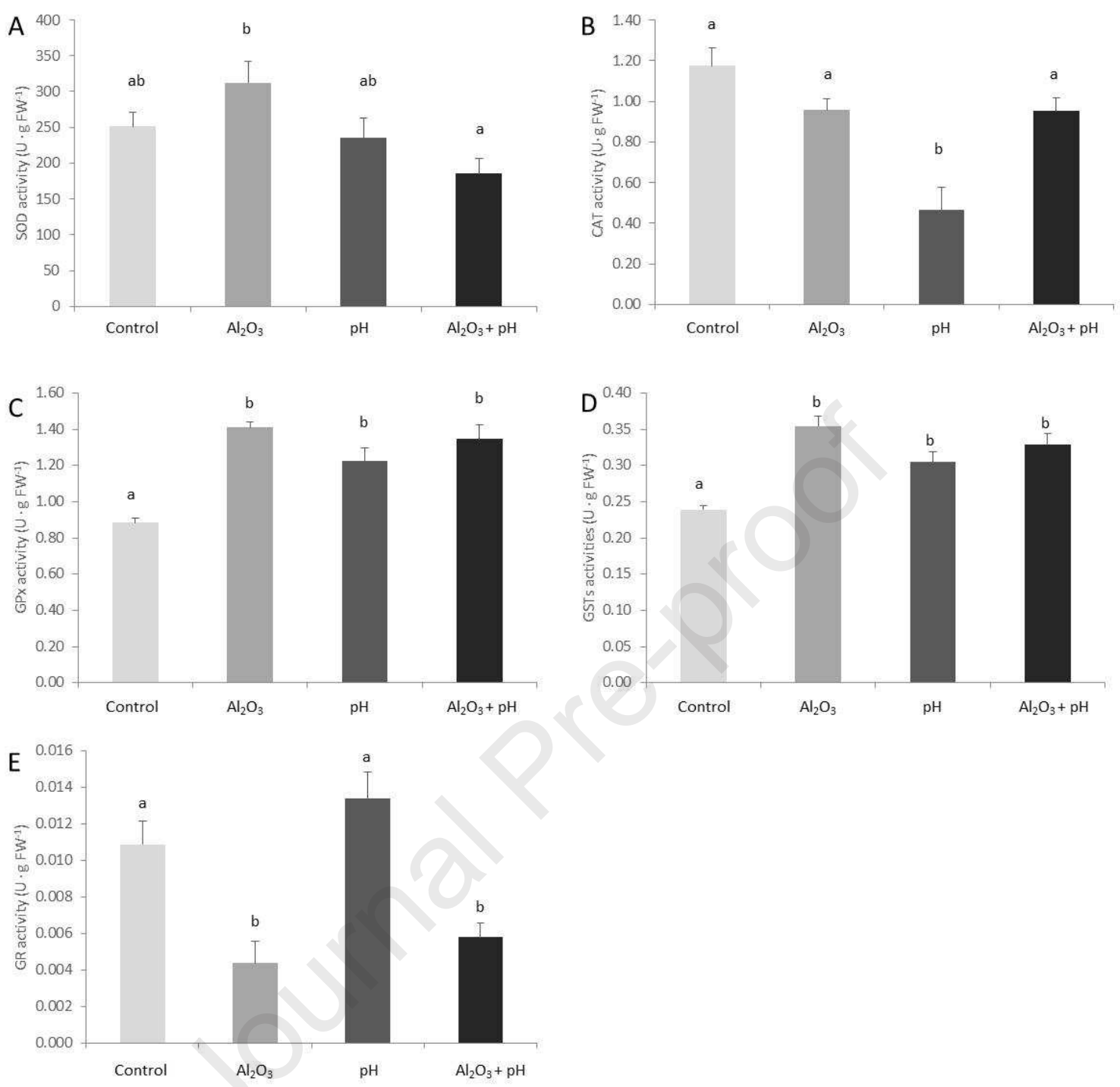

Figure 3: Antioxidant and biotransformation activities (means \pm SEM) measured in $M$. jelskii under the different treatments: A) Superoxide dismutase (SOD); B) Catalase (CAT); C) Glutathione peroxidase (GPx); D) Glutathione Stransferases (GSTs); E) Glutathione reductase (GR). Values associated to different letters are statistically different from each other, according to a one-way ANOVA test followed by a Student-Newman-Keuls a-posteriori multiple comparison test.

conditions, although the patterns varied among the enzymes measured. SOD activity showed

the highest values in animals exposed to increased $\mathrm{Al}_{2} \mathrm{O}_{3}$ concentrations, while the lowest

values were shown by animals exposed to the combination of $\mathrm{Al}_{2} \mathrm{O}_{3}$ and reduced $\mathrm{pH}(\mathrm{F}=4.335$; $p=0.034$ ) (Figure 3A). CAT activity, however, showed similar values across conditions, for the 

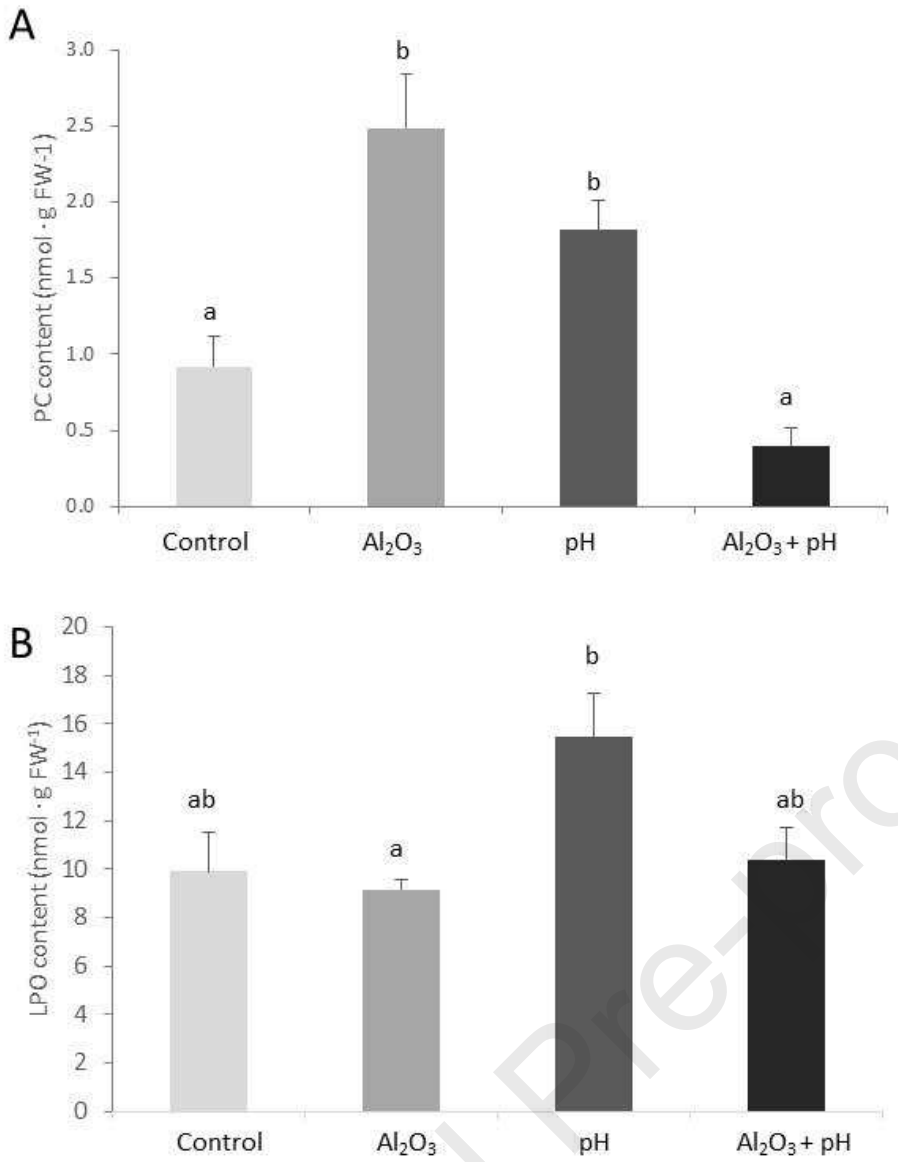

Figure 4: Oxidative damage markers (means \pm SEM) measured in $M$. jelskii under the different treatments: A) protein carbonyl (PC) content; B) peroxidized lipid (LPO) (malondialdehyde-like compounds) content. Values associated to different letters are statistically different from each other, according to a one-way ANOVA test followed by a Studentsole Newman-Keuls a-posteriori multiple comparison test.

334 exposed to reduced $\mathrm{pH}$, for which values were in average 2 -fold lower $(\mathrm{F}=11.585 ; p=0.001)$

335 (Figure 3B). GPx (Figure 3C) and GSTs activities (Figure 3D) showed precisely the same pattern, with all conditions showing significantly increased values compared to controls (GPx: $F=17.323$; $p=0.001$. GSTs: $\mathrm{F}=17.228 ; p<0.001)$. GR activity was significantly lower in those animals exposed to increased $\mathrm{Al}_{2} \mathrm{O}_{3}$ in the water, accompanied or not with a decrease in environmental $\mathrm{pH}(\mathrm{F}=11.917 ; p=0.001)$ (Figure 3E).

\subsection{Oxidative damage}

341 Both protein and lipid damage values showed significant differences among conditions. Protein carbonyl content was highest in animals exposed to decreased $\mathrm{pH}$ and increased $\mathrm{Al}_{2} \mathrm{O}_{3}$ alone 
$343(\mathrm{~F}=18.906 ; p<0.001)$. However, animals subjected to the combination of these two factors

344 showed values that did not differ from controls (Figure 4A). Contrarily, MDA content

345 (associated with lipid peroxidation) was most affected by low $\mathrm{pH}$, with animals exposed to

346 decrease environmental $\mathrm{pH}$ showing 1.5-fold higher MDA content than controls ( $F=6.697$;

$347 p=0.045$ ) (Figure 4B).
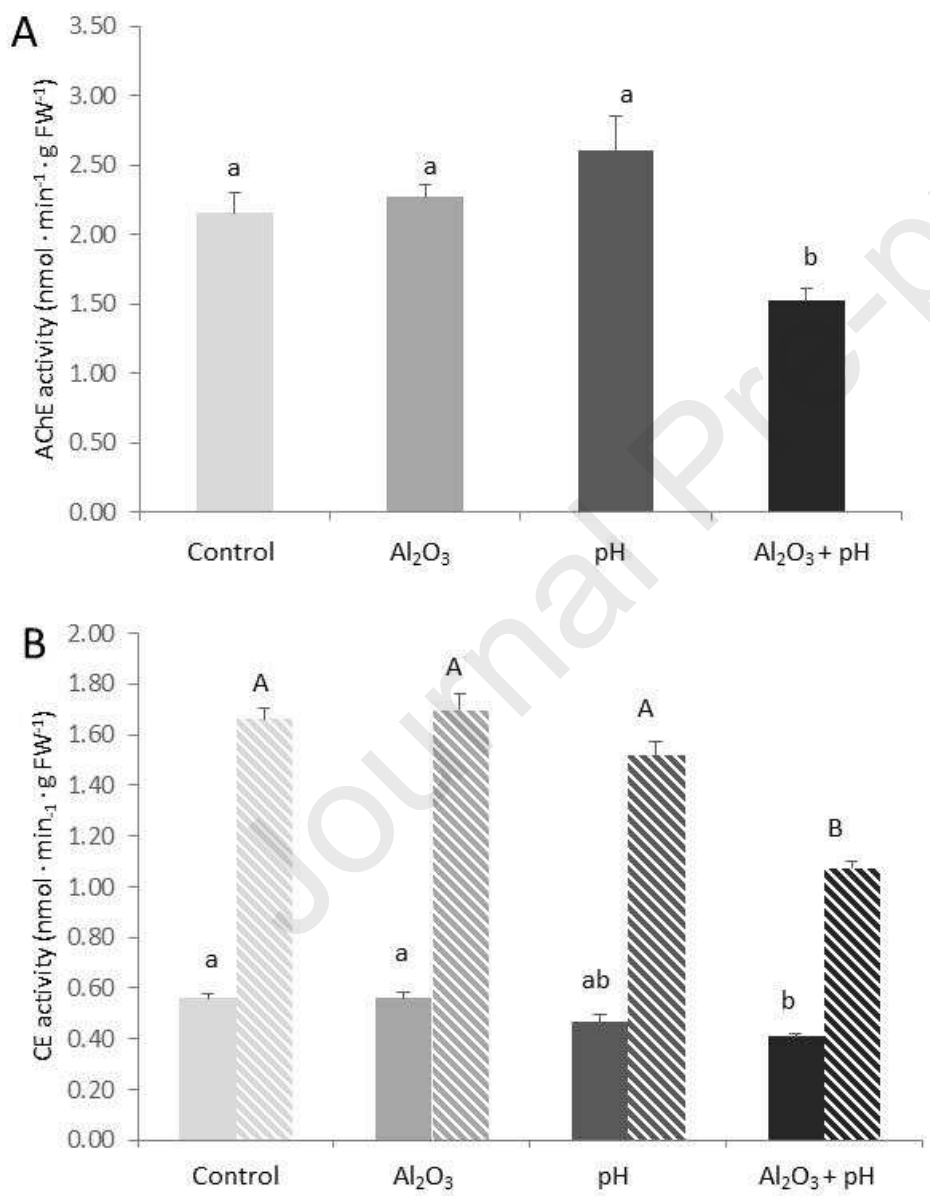

Figure 5: Activity values as (means \pm SEM), corresponding to: A) acetylcholinesterase (AChE) activity and B) Carboxylesterase activity, measured using PNPA and PNPB as substrates (plain-colored and stripped bars, respectively). Values associated to different letters are statistically different from each other, according to a oneway ANOVA test followed by a Student-Newman-Keuls a-posteriori multiple comparison test.

354 AChE activity was significantly lower (by 1.5 -fold) in organisms exposed to $\mathrm{Al}_{2} \mathrm{O}_{3}$ at low $\mathrm{pH}$ in 355 comparison to the remaining conditions ( $\mathrm{F}=7.657 ; p=0.005)$ (Figure $5 \mathrm{~A})$. CEs showed a similar pattern, although activities measured with $\rho N P B$ as substrate yielded higher hydrolysis rates 
357

358

359

360

361

362

363

364

365

366

367

368

369

370

371

372

373

374

375

376

377

378

379

380

than with $\rho N P A$. In both cases, activities were the lowest under $\mathrm{Al}_{2} \mathrm{O}_{3}$ exposure at low $\mathrm{pH}$ ( $\rho N P A: F=7.820 ; p=0.006 . \rho N P B: F=27.161 ; p<0.001$ ) (Figure 5B).

\section{DISCUSSION}

The present study documents the hazard of anthropogenic acidification and micron-sized $\mathrm{Al}_{2} \mathrm{O}_{3}$ pollution in the context of space port launching activities. To the authors' knowledge, our study is the first to address this subject using an energy-redox approach in an aquatic invertebrate. Ecological studies carried out around the Ariane 5 launch pad in French Guiana revealed that the biodiversity and abundance of aquatic invertebrates such as Diptera larvae are comparable to control values three weeks after a launch (Vigouroux, pers. obs.). However, it is known that compared to such ecological approaches (consisting on taxonomical or traitbased metrics), eco-physiological parameters can significantly reduce the threshold at which stress can be detected. This study provides evidence that launch activities impact the shrimps at a biochemical and physiological levels. Thus, it would therefore be advisable to reproduce the same studies over a time step closer to a launch and to integrate these physiological analyses in-situ to select a set of early-warning biomarkers for their potential implementation in future monitoring programs.

$\mathrm{Al}_{2} \mathrm{O}_{3}$ exposure impairs aquatic respiration and leads to oxidative damage

Our results show that even if $\mathrm{Al}_{2} \mathrm{O}_{3}$ is only scarcely hydrosoluble at circumneutral pH, M. jelskii exposed to $0.5 \mathrm{mg} \mathrm{L}^{-1}$ of $\mathrm{Al}_{2} \mathrm{O}_{3}$ accumulate $\mathrm{Al}$ in their body, with values reaching almost double the concentrations of control (undisturbed) animals. Given its low solubility at normal pH (6.6), we hypothesize that that this accumulation must occur mostly through particle ingestion.

Regardless of the uptake pathway, $\mathrm{Al}_{2} \mathrm{O}_{3}$ exposure under normal $\mathrm{pH}$ caused animals to significantly increase their RRs. Such a response has also been observed by Herrmann and Andersson (1986) in two species of lotic mayflies exposed to increasing amounts of aluminum 
381

382

sulfate in the water (in the range of the values here used). Another study carried out in rainbow trout also registered an increase in RR within the first 3 days of exposure to aluminum sulfate although values decreased after that time (Neville, 1985). But despite the increased RR, ETC activity was 1.6 times lower than the control group, leading us to hypothesize that respiration was impaired. "The gills are the major site of interactions between waterborne toxic metals and the organism in aquatic Crustacea" (Henry et al., 2012) and it has been observed that aquatic organisms exposed to Al-rich waters accumulate Al on their gills (reviewed by Rosseland et al., 1990). When dealing with more soluble Al compounds (aluminum sulfates, nitrates, etc.), this occurs in the form of aluminum hydroxide $\left(\mathrm{Al}(\mathrm{OH})_{3}\right)$ and presumably due to the negative charge of the gill mucus (McDonald, 1983). But the scarcely hydrosoluble soluble micro-particles like the ones used in this study, are nevertheless recognized by the immune system as foreign bodies and leading to the induction of the mucosal immune response. In consequence, exposure to $\mathrm{Al}_{2} \mathrm{O}_{3}$ may produce, as $\mathrm{Al}$ does, inflammation of gill tissues and proliferation of mucus cells (reviewed by Rosseland et al., 1990). An overproduction of mucus may block oxygen uptake and eventually lead to gill clogging and a decrease of respiration efficiency through a "mechanical impact route" (Herrmann and Andersson, 1986). Without further confirmation through histological examination, we hypothesize that animals may be hyperventilating under these conditions, as has been seen to happen in other organisms (Malte and Weber, 1988), in an attempt to increase $\mathrm{O}_{2}$ uptake and fight an increasing functional hypoxia.

Despite a decreased ETC activity, we can presume that there is enhanced RONS production, inducing oxidative stress as evidenced by the 2.7-times higher PC levels registered in the $\mathrm{Al}_{2} \mathrm{O}_{3^{-}}$exposed group. In the nematode Caenorhabditis elegans, exposure to $\mathrm{Al}_{2} \mathrm{O}_{3}$ nanoparticles indeed increased RONS formation, as shown by the $2^{\prime}, 7^{\prime}$ dichlorofluorescein fluorescence assay (Li et al., 2012). The source of these RONS could be various: i) due to direct exposure to $\mathrm{Al}_{2} \mathrm{O}_{3}$ and/or alterations on mitochondrial activity; ii) because $\mathrm{Al}_{2} \mathrm{O}_{3}$ may, as $\mathrm{Al}$ does, be 
407 increasing intracellular Fe concentrations through various pathways (e.g. Wu et al., 2012) and

408 thus promoting the Fenton reactions; iii) as the result of the immune response, carried out mainly by haemocytes which produce RONS during the phagocytic process of foreign particles

410 (Oyanedel et al., 2016).

411 The activities of GSTs and GPx were significantly increased upon changes in environmental 412 conditions. Their synthesis, as well as that of other new molecules to face the stress, may 413 explain the increased PROT levels. But these defense mechanisms would require additional 414 energetic demands (e.g. Novais et al., 2013). This has been observed in other freshwater invertebrates exposed to heavy metal pollution, which resulted in depleted GLY reserves (e.g. Rajalekshmi and Mohandas, 1993). However, in the present study GLY contents were higher compared to control values (as seen in other models) (e.g. Chinoy and Memon, 2001), leading us to hypothesize that sources of energy other that GLY are being mobilized. Among the antioxidants analyzed, $\mathrm{GR}$ activity was the most clearly affected by $\mathrm{Al}_{2} \mathrm{O}_{3}$, with decreased activities under both normal and acidified conditions. GR is a key enzyme in the maintenance of the redox homeostasis. It is responsible for reducing oxidized glutathione (GSSG) to renew the reduced glutathione (GSH) pool, "the heart of one of the most important cellular antioxidant systems" (Couto et al., 2016). Similar GR depletions when exposed to heavy metals have been registered in freshwater bivalves (Guidi et al., 2010) or fish (Giguère et al., 2005). The latter fish study suggested that this could be due to the metal binding to the enzyme functional group. Some reports demonstrate that metal cations such as $\mathrm{Zn}^{+}, \mathrm{Cd}^{2+}, \mathrm{Cu}^{2+}$ or $\mathrm{Fe}^{2+}$ 427 (this varying among animal species) can induce redox inactivation of GR (Christie and Costa, 1984; Peinado et al., 1991; Cardoso et al., 2008). However, to the authors knowledge there is no information that Al cations could induce similar effects. Another possibility is that GR is inactivated due to the lack of NADPH, a co-enzyme that is required to catalyze the reduction of GSSG. The major source of NADPH in the cell is the pentose phosphate pathway through the 
433

434

435

436

437

438

inhibited by Al in various models, such as Saccharomices cerevisiae (Cho and Joshi, 1989) and human erythrocytes (Bulat et al., 2008).

Altogether, and despite the increase of antioxidant activities, the results obtained are suggestive of an excess of RONS formation, causing a misbalance between oxidant and antioxidant pathways in favor of the first, and induce oxidative stress. This stress would be mainly affecting the protein fraction of the cells, increasing PC levels significantly. Similar results have been recorded for fish species using aluminum sulfate (García-Medina et al., 2010). Altogether, these results suggest a link between $\mathrm{Al}$ and protein damage through the mediation of Al- or respiratory-induced RONS formation.

\section{A decrease in $\mathrm{pH}$ reduces baseline $\mathrm{Al}$ but increases energetic requirements and oxidative stress}

Aluminum is the third most abundant element on the Earth's crust, and is commonly present in continental water bodies. Water acidification promotes the mobilization of Al from the edaphic to the aquatic environment, further increasing the concentrations to which aquatic fauna are exposed. In the present study low $\mathrm{pH}$ alone actually reduced the presence of $\mathrm{Al}$ in tissues by half (compared to controls). However, the increased RR showed by animals under low $\mathrm{pH}$ could be contributing to fuel higher detoxification rates (which may potentially be facilitated by the higher solubility of Al under acidified conditions), causing its accumulation to be reduced compared to control values. As it will be discussed further below, this would be possible under lower (natural) Al concentrations, and not being the case at increased levels when animals are under higher levels of stress.

A decrease in environmental $\mathrm{pH}$ had important effects on the energy-redox parameters in $M$. jelskii. This condition caused RRs to increase in the shrimps compared to controls, and though maintaining comparable ETC activities, this would be supplying the cells with the necessary energy to maintain $\mathrm{pH}$ homeostasis. Maintenance of intracellular acid-base balance is essential for normal physiology and metabolic function, and it is achieved through various processes, 
among which we find two energy-consuming processes. The first, the transfer of acid and/or base equivalents across the cell membrane (namely electroneutral exchanges of $\mathrm{HCO}_{3}{ }^{-}$for $\mathrm{Cl}^{-}$ and $\mathrm{Na}^{+}$for $\mathrm{H}^{+}$) (Henry and Wheatly, 1992), which depends on the ion gradient produced by active transporters such as the $\mathrm{Na}^{+} / \mathrm{K}^{+}$- and the $\mathrm{H}^{+}$-ATPases (reviewed by Whiteley, 2011). And second, transmembrane protein synthesis and activity (Deigweiher et al., 2010), which under decreased $\mathrm{pH}$ has been estimated to require an allocation of up to $84 \%$ of the total energy available (Pan et al., 2015). Thus, such compensatory processes may well be explaining the increased RR observed in the present study. Such RR increases have also been documented for marine organisms, although freshwater examples are scarce. Many studies already addressed this in the context of climate change and $\mathrm{CO}_{2}$-induced seawater acidification. Compared to freshwater systems, $\mathrm{pH}$ changes in the marine environment are much smaller but they provide a source of comparison. For example, at small pH changes (decrease in 0.4-1.2 units), some studies have shown increases in RR in echinoderms (e.g. Wood et al., 2008; Stumpp et al., 2011) or marine gastropods (e.g. Thomsen and Melzner, 2010). However, larger pH shifts in the marine environment are often needed to lead to metabolic depression (e.g. Pörtner et al., 2004). In freshwater systems, water acidification also occurs, with pH shifts being considerably larger than in marine systems. For the particular case of the water bodies of French Guiana, pH values are often as low as 5.5-6.0 and in some very lentic water courses it may decrease down to 4.5 (Dedieu et al., 2015; Crespy et al., 2019), i.e. the pH value used in this study. Thus, adapted to such acidic values, $M$. jelskii is capable of maintaining high RRs (at low pH alone) and avoiding metabolic depression.

Nevertheless, the observed increase in RR could also be responsible for an increase in RONS formation, depleting specific antioxidant reserves such as CAT. The same was observed for a marine shrimp (Litopenaeus vannamei) exposed to decreased $\mathrm{pH}$ (6.7), where CAT was decreased after 7 days of exposure (Han et al., 2018). Overall, this CAT depletion may be partly 
484

485

486

487

488

489

490

491

492

493

494

495

496

497

498

499

500

501

502

503

504

505

506

507

508

damaging both the protein and the lipid fractions of the cells. This agrees with previous studies revealing that, under similar conditions, the yeast Saccharomyces cerevisae suffered also from cellular membrane damage (García-Saucedo et al., 2011), or in the shrimp L. vannamei which also showed increased MDA under decreased pH conditions (Han et al., 2018).

$\mathrm{Al}_{2} \mathrm{O}_{3}$ microparticle pollution at low $\mathrm{pH}$ causes a synergic effect, inducing neurotoxicity and metabolic depression.

Usually, at lower $\mathrm{pH}$ Al becomes more bioavailable and crustaceans tend to accumulate higher concentrations (Rejeki, 2003). Despite $\mathrm{Al}_{2} \mathrm{O}_{3}$ not being as hydrosoluble as aluminum sulfates and nitrates commonly used in other Al-toxicity studies, its solubility still increases under acidic conditions. This may be determining different uptake pathways than when $\mathrm{Al}_{2} \mathrm{O}_{3}$ microparticles are under less soluble form. Despite this, the Al concentration values registered in animals exposed to $\mathrm{Al}_{2} \mathrm{O}_{3}$ at normal (6.6) and acid (4.5) pH conditions were similar. We may consider two possible reasons for this: i) technically speaking, because the method here used to quantify $\mathrm{Al}$ in the tissues may have certain technical limitations avoiding us to register higher accumulation under acidic conditions; and ii) biologically, probably due to the animals presenting lower ventilation rates (decreased scaphognathite beating) under the context of a probable metabolic depression under this combined pressure.

Even if we did not register higher Al bioaccumulation at lower $\mathrm{pH}$, it is evident from the present results that the combined effect of Al under acidified conditions impacted animal physiology at higher levels. In the present study, one of the most relevant conclusions is that $\mathrm{Al}_{2} \mathrm{O}_{3}$ under low $\mathrm{pH}$ had neurotoxic impact on $M$. jelskii. This is shown by both decreased AChE and CE activities in the animals. Al is a known neurotoxic contaminant (Kaizer et al., 2008), and AChE activity is a good biomarker for this purpose in aquatic invertebrates (e.g. Forget et al., 2003). CEs, which have already been characterized for M. jelskii (Lima et al., 2013), are also 
510 works reporting their decrease as a result of exposure to trace metals in other aquatic species

511 (de Lima et al., 2013). In the context of this study, the decrease of both esterases (AChE and

512 CEs activities) were a clear indicator of the synergic impact that $\mathrm{pH}$ and $\mathrm{Al}_{2} \mathrm{O}_{3}$ exposure had on M. jelskii. Given that animals under these conditions did not show higher Al accumulation than animals exposed to $\mathrm{Al}_{2} \mathrm{O}_{3}$ alone, we hypothesize that this is a genuine biochemical synergism and not just the effect of increased Al availability under acidic conditions.

In a bioenergetics framework, exposure to low $\mathrm{pH}$ or $\mathrm{Al}_{2} \mathrm{O}_{3}$ alone would constitute a moderate stress situation for M. jelskii. Under such conditions ATP would be still supplied by aerobic metabolism alone and this energy would be devoted to fulfilling the increasing needs of maintenance processes (e.g. extra-cellular protection and repair) in detriment of others such as growth or reproduction ("pejus range") (see Fig. 1 in Sokolova et al., 2012). But the combination of low pH and increased $\mathrm{Al}_{2} \mathrm{O}_{3}$ would be an extreme stress situation ("pessimum range") where animals will need to rely partly on anaerobic metabolism (nil aerobic scope) and all available energy would be directed towards maintenance alone (Sokolova et al., 2012). Such a metabolic depression is far from uncommon in nature, and countless examples can be found in the literature. For example, for cyprinid fish exposed to trace metals, metabolic depression has been determined to occur when metal concentrations in the environment overpass $40 \%$ of

527 the maximum sub-lethal level (Peles et al., 2012). The fact that PC concentrations were 528 significantly lower than when animals were exposed to $\mathrm{Al}_{2} \mathrm{O}_{3}$ or $\mathrm{pH}$ alone, further support the hypothesis that M. jelskii enters a state of reduced metabolism, and while no mortality rates were registered, we may hypothesize that this provides a way for animals to prolong survival until the return of more tolerable environmental conditions.

532 To the authors' knowledge there are no studies addressing the specific pathways in which $533 \mathrm{Al}_{2} \mathrm{O}_{3}$ harms aquatic species under low $\mathrm{pH}$. For general Al toxicity, this equally remains 
534

535

536

537

538

539

540

541

542

543

544

545

546

547

548

549

550

551

552

553

554

555

556

557

558

relatively unknown, but it has been attributed to Al decreasing the tolerance of benthic invertebrates to water acidification through the impairment of osmoregulation processes (reviewed by Herrmann, 1987). Indeed, negative effects caused by inorganic Al exposure under acidified conditions have been observed for freshwater fish and invertebrates (e.g. Herrmann, 1987; Leino and McCormick, 1993). In the freshwater fish Micropterus salmoides, Leino and McCormick (1993) observed that under $30 \mu \mathrm{g} \mathrm{L}^{-1}$ monomeric $\mathrm{Al}$ and a $\mathrm{pH}$ of 4.5 , key osmoregulatory organs such as gills were obliterated by hyperplasia of the interlamellar epithelium and showed over a 2-fold decrease in the amount of chloride (mitochondria-rich) cells. Leivestad et al. (1987), on the other hand, demonstrated in salmon that Al exposure can reduce the activity of $\mathrm{Na}^{+}-\mathrm{K}-\mathrm{ATPase}$, key transporter in ensuring osmoregulation. Altogether, results suggest that the Al-induced respiratory disability may additionally be leading to osmoregulatory impairment when exposure occurs under acidified conditions.

\section{CONCLUSIONS AND FUTURE PERSPECTIVES}

In the Anthropocene era, it has become imperative to identify appropriate indicators to predict biodiversity changes. While taxonomy- or trait-based approaches can provide means of "drawing the rough edges", ecophysiological metrics often provide early warning signs because they are detectable at lower stress threshold levels (Branquinho et al., 2019). By applying such tools, altogether, our results support the hypothesis that $\mathrm{Al}_{2} \mathrm{O}_{3}$ (through direct exposure or even ingestion of undissolved particles) impairs respiration and oxidative status of M. jelskii. However, under acidified conditions, $\mathrm{Al}_{2} \mathrm{O}_{3}$ induces neurotoxicity and metabolic depression in this shrimp species. Further works should aim to confirm if this is due to the disruption of the acid-base homeostasis through either mechanistic (e.g. inhibition of certain transporters, alterations of the gill function) or energetic pathways (failure to deliver enough oxygen to deal with the energetic requirements for osmoregulation). 
559 Regarding the combined effect of $\mathrm{pH}$ and $\mathrm{Al}_{2} \mathrm{O}_{3}$ exposure (which are the real conditions found

560 around the launch pads), the biomarkers that resulted most informative to reach our

561 conclusions were the neurotoxicity parameters (AChE and CEs), GR activities and RRs. From a

562 practical point of view these are important conclusions, given that the identification of

563 biomarkers to assess environmental quality is a major issue in the field of ecotoxicology. By

564 using a shrimp species belonging to a world-distributed family, our results set the bases for

565 providing the metrics and reference values to be used with an active biomonitoring approach.

566 This would ultimately allow understanding the complexity of the biochemical and physiological

567 responses to such contaminants. Even though the results of this study must be validated in the

568 field, the inclusion of these biomarkers in future monitoring programs of space port launching

569 activities based on propergol fuel should be considered.

570 Future works should focus on how and where $\mathrm{Al}_{2} \mathrm{O}_{3}$ bioaccumulation is occurring in M. jelskii

571 under normal and acidified conditions, and if as for other species, gills are impacted.

572 Additionally, the consequences that the combined ecotoxicological effects with other

573 pollutants (metals, plastics, fuels, etc.) or even with eutrophication and other climate-change

574 related stressors may have on macrofauna and the trophic chain remain completely unknown.

575 Given that detoxification capacity was reduced under $\mathrm{Al}_{2} \mathrm{O}_{3}$ exposure at low pH (low CE

576 activities), this subject should be urgently addressed in both aquatic and terrestrial ecosystems

577 to better predict the impact of launchers in the context of increasing activities of space ports

578 worldwide.

\section{ACKNOLEDGEMENTS}

581 The authors would like to thank Carla Leite (University of Aveiro, Portugal) and Stéphanie

582 Raffestin (Institute Pasteur, French Guiana), for carrying out the quantification of Al in shrimp

583 tissues and water samples, respectively. Special thanks go to Eduarda Pereira (University of 

and Damien Monchaux (Hydreco Guyane) for their support throughout the experimental setup, to Greg Quartarollo (Hydreco Guyane) for doing the taxonomic identification of the experimental animals, and to Manon Guilaut, Pauline Le Page and Candice Thomas for the help in the animal collection. We are also grateful to the two anonymous referees for their constructive comments which helped improving the original version of this manuscript. conducted the biochemical analyses. All authors contributed to data interpretation, manuscript writing, review and editing.

\section{REFERENCES}

Beauchamp, G., Fridovich, I., 1971. Superoxide dismutase: improved assays and an assay applicable to acrylamide gels. Anal. Biochem. 44, 276-287.

598 Bousquet, C., 2017. Les lancements dans le monde. Latitude 5. CNES/Centre Spatial Guyanais, 599 Kourou, pp. 32-33.

600 Branquinho, C., Serrano, H.C., Nunes, A., Pinho, P., Matos, P., 2019. Essential biodiversity 601 change indicators for evaluating the effects of Anthropocene in ecosystems at a global scale. From Assessing to Conserving Biodiversity. Springer, Cham, pp. 137-163. Buege, J.A., Aust, S.D., 1978. Microsomal lipid peroxidation. Methods Enzymol. 52(C), 302-310. Bulat, P., Potkonjak, B., Đujić, I., 2008. Lipid Peroxidation and Antioxidative Enzyme Activity in Erythrocytes of Workers Occupationally Exposed to Aluminium. Arh. Hig. Rada. Toksikol. 59, 81.

Cardoso, L.A., Ferreira, S.T., Hermes-Lima, M., 2008. Reductive inactivation of yeast glutathione reductase by Fe (II) and NADPH. Comp. Biochem. Physiol. A: Mol. Integr. Physiol. 151, 313-321.

Carlberg, I., Mannervik, B., 1985. Glutathione reductase. Methods Enzymol. 113, 484-490.

Cencetti, M., Veilleur, V., Albergel, A., Olry, C., 2007. SARRIM: a tool to follow the rocket releases for the CNES environment and safety division on the European Spaceport of Kourou (French Guyana). 11th International Conference on Harmonisation within Atmospheric dispersion modelling for regulatory purposes, Cambrigde, UK.

Chinoy, N.J., Memon, M.R., 2001. Beneficial effects of some vitamins and calcium on fluoride and aluminium toxicity on gastrocnemius muscle and liver of male mice. Fluoride 34, 21-33.

Cho, S.-W., Joshi, J., 1989. Time-dependent inactivation of glucose-6-phosphate dehydrogenase from yeast by aluminum. Toxicology letters 47, 215-219.

620 Trace Elem. Res. 6, 139-158. 
Clavier, S., Le Reun, S., Reynouard, C., 2017. Etude d'impact des milieux aquatiques du projet d'implantation des bâtiments EFF et BSB en saison sèche CSG - Rapport HYDRECO / ANTEA, 623 French Guiana, p. 62.

624 Collins, P.A., 2000. A new distribution record for Macrobrachium jelskii (Miers, 1877) in 625 Argentina (Decapoda, Palaemonidae). Crustaceana (Leiden) 73, 1167-1169.

626 Couto, N., Wood, J., Barber, J., 2016. The role of glutathione reductase and related enzymes on cellular redox homoeostasis network. Free Rad. Biol. Med, 95, 27-42. Crespy, F., Bargier, N., Monchaux, D., 2019. Réseau de Contrôle Opérationnel des eaux douces de surface 2018/2019 - District hydrographique de la Guyane - Mesures in situ, paramètres chimiques et physico-chimiques analysés HYDRECO - Office de l'Eau de Guyane, French Guiana, p. 111.

De Coen, W.M., Janssen, C.R., 1997. The use of biomarkers in Daphnia magna toxicity testing. IV. Cellular energy allocation: a new methodology to assess the energy budget of toxicantstressed Daphnia populations. J. Aquat. Ecosyst. Stress Recovery 6, 43-55.

De Lacour, G., 2011. Lancer des fusées: un danger pour les Guyanais? Journal de I'Environnement. InfoPro Digital, Antony Cedex France.

de Lima, D., Roque, G.M., De Almeida, E.A., 2013. In vitro and in vivo inhibition of acetylcholinesterase and carboxylesterase by metals in zebrafish (Danio rerio). Mar. Environ. Res. 91, 45-51.

Dedieu, N., Vigouroux, R., Cerdan, P., Céréghino, R., 2015. Invertebrate communities delineate hydro-ecoregions and respond to anthropogenic disturbance in East-Amazonian streams. Hydrobiologia 742, 95-105.

Deigweiher, K., Hirse, T., Bock, C., Lucassen, M., Pörtner, H.O., 2010. Hypercapnia induced shifts in gill energy budgets of Antarctic notothenioids. J. Comp. Physiol. B Biochem. Syst. Environ. Physiol. 180, 347-359.

Dubois, M., Gilles, K.A., Hamilton, J.K., Rebers, P.T., Smith, F., 1956. Colorimetric method for determination of sugars and related substances. Anal. Chem. 28, 350-356.

648 Duggleby, R.G., 1984. Regression analysis of nonlinear Arrhenius plots: An empirical model and 649 a computer program. Comput. Biol. Med. 14, 447-455.

650 Ellman, G.L., Courtney, K.D., Andres Jr, V., Featherstone, R.M., 1961. A new and rapid 651 colorimetric determination of acetylcholinesterase activity. Biochem. Pharmacol. 7, 88-95. Forget, J., Beliaeff, B., Bocquené, G., 2003. Acetylcholinesterase activity in copepods (Tigriopus brevicornis) from the Vilaine River estuary, France, as a biomarker of neurotoxic contaminants. Aquatic Toxicol. 62, 195-204. García-Medina, S., Razo-Estrada, A.C., Gómez-Oliván, L.M., Amaya-Chávez, A., MadrigalBujaidar, E., Galar-Martínez, M., 2010. Aluminum-induced oxidative stress in lymphocytes of common carp (Cyprinus carpio). Fish Physiol. Biochem. 36, 875-882. $\mathrm{SiO}_{2} \mathrm{Al}_{2} \mathrm{O}_{3}$ and $\mathrm{CeO}_{2}$ nanoparticles to the yeast, Saccharomyces cerevisiae. J. Hazard $\mathrm{Mater}$ 192, 1572-1579.

Giguère, A., Campbell, P.G.C., Hare, L., Cossu-Leguille, C., 2005. Metal bioaccumulationa nd oxidative stress in yellow perch (Perca flavescens) collected from eight lakes along a metal contamination gradient (Cd, Cu, Zn, Ni). Can. J. Fish. Aquat. Sci. 62, 563-577.

Gonçalves de Miranda, F., 2000. Estude numérique de l'écoulement instationnaire diphasique dans les propulseurs à propergol solide d'Arine 5. Energétique et Dynamique des Fluides. Ecole Nationale Superieure de l'aeronautique et de l'espace, France, p. 205.

Guidi, P., Frenzilli, G., Benedetti, M., Bernardeschi, M., Falleni, A., Fattorini, D., Regoli, F., Scarcelli, V., Nigro, M., 2010. Antioxidant, genotoxic and lysosomal biomarkers in the freshwater bivalve (Unio pictorum) transplanted in metal polluted river basin. Aquat. Toxicol. (Amst.) 100, 75-83.

Habig, W.H., Pabst, M.J., Jakoby, W.B., 1974. Glutathione S-transferases: the first enzymatic step in mercapturic acid formation. J. Biol. Chem. 249, 7130-7139. 
Halatek, T., Sinczuk-Walczak, H., Rydzynski, K., 2005. Prognostic significance of low serum levels of Clara cell phospholipid-binding protein in occupational aluminium neurotoxicity. J. Inorg. Biochem. 99, 1904-1911.

Han, S.-Y., Wang, M.-Q., Wang, B.-J., Liu, M., Jiang, K.-Y., Wang, L., 2018. A comparative study on oxidative stress response in the hepatopancreas and midgut of the white shrimp Litopenaeus vannamei under gradual changes to low or high $\mathrm{pH}$ environment. Fish Shellfish Immunol. 76, 27-34. Harvey, B., 2003. Europe's space programme - To Ariane and beyond. Springer, London, UK. Henry, R.P., Lucu, C., Onken, H., Weihrauch, D., 2012. Multiple functions of the crustacean gill: osmotic/ionic regulation, acid-base balance, ammonia excretion, and bioaccumulation of toxic metals. Front. Physiol. 3, 431. Henry, R.P., Wheatly, M.G., 1992. Interaction of respiration, ion regulation, and acid-base balance in the everyday life of aquatic crustaceans. Am. Zool. 32, 407-416. Herrmann, J., 1987. Aluminium impact on freshwater invertebrates at low pH: A review. In: Landner, L. (Ed.). Speciation of metals in water, sediment and soil systems. Springer-Verlag, Berlin, Germany, pp. 157-175.

Herrmann, J., 2001. Aluminum is harmful to benthic invertebrates in acidified waters, but at what threshold (s)? Water, air, and soil pollution 130, 837-842.

Herrmann, J., Andersson, K.G., 1986. Aluminium impact on respiration of lotic mayflies at low pH. Water Air Soil Pollut. 30, 703-709.

Holthuis, L.B., Ng, P.K.L., 2009. Nomenclature and taxonomy. In: New, M.B., Valenti, W.C., Tidwell, J.H., D'Abramo, L.R., Kutty, M.N. (Eds.). Freshwater prawns: biology and farming. Blackwell Publishing Ltd.

Hosokawa, M., Satoh, T., 2005. Measurement of carboxylesterase (CES) activities. In: Costa, L.G., Hodgson, E., Lawrence, D.A., Ozolins, T.R., Reed, D.J., Greenlee, W.F. (Eds.). Current protocols in toxicology. John Wiley \& Sons, NJ, USA.

Johansson, L.H., Borg, L.A., 1988. A spectrophotometric method for determination of catalase activity in small tissue samples. Anal. Biochem. 174, 331-336.

701 Kaizer, R., Correa, M., Gris, L., Da Rosa, C., Bohrer, D., Morsch, V., Schetinger, M.R.C., 2008.

702 Effect of long-term exposure to aluminum on the acetylcholinesterase activity in the central nervous system and erythrocytes. Neurochem. Res. 33, 2294-2301. Leino, R.L., McCormick, J.H., 1993. Responses of juvenile largemouth bass to different pH and aluminum levels at overwintering temperatures: effects on gill morphology, electrolyte balance, scale calcium, liver glycogen, and depot fat. Can. J. Zool. 71, 531-543. Leivestad, H., Jensen, E., Kjartasson, H., Xingfu, L., 1987. Aqueous speciation of aluminium and toxic effects on Atlantic salmon. Annls. Soc. R. Zool. Belg. 117, 387-398. Li, M., Czymmek, K.J., Huang, C., 2011. Responses of Ceriodaphnia dubia to $\mathrm{TiO}_{2}$ and $\mathrm{Al}_{2} \mathrm{O}_{3}$ nanoparticles: a dynamic nano-toxicity assessment of energy budget distribution. J. Hazard. Mater. 187, 502-508.

$\mathrm{Li}, \mathrm{Y}$., Yu, S., Wu, Q., Tang, M., Pu, Y., Wang, D., 2012. Chronic $\mathrm{Al}_{2} \mathrm{O}_{3}$-nanoparticle exposure causes neurotoxic effects on locomotion behaviors by inducing severe ROS production and disruption of ROS defense mechanisms in nematode Caenorhabditis elegans. J. Hazard. Mater. 219-220, 221-230.

Lima, A.V.B., Guerra, A.L., de Almeida, E.A., Taddei, F.G., Castiglioni, L., 2013. Characterization of esterase patterns in hepatopancreas of three species of Macrobrachium (Palaemonidae). Biochem. Syst. Ecol. 47, 132-138.

Lowry, O.M., Rosenbrough, N.J., Farr, O.L., Randall, R.J., 1951. Protein measurement with the folin phenol reagent. J. Biol. Chem. 193, 265-275.

Malte, H., Weber, R.E., 1988. Respiratory stress in rainbow trout dying from aluminium exposure in soft, acid water, with or without added sodium chloride. Fish Physiol. Biochem. 5, 249-256. 
McDonald, D., 1983. The effects of H+ upon the gills of freshwater fish. Can. J. Zool. 61, 691703.

Mennillo, E., Casu, V., Tardelli, F., De Marchi, L., Freitas, R., Pretti, C., 2017. Suitability of cholinesterase of polychaete Diopatra neapolitana as biomarker of exposure to pesticides: In vitro characterization. Comp. Biochem. Physiol. C: Toxicol. Pharmacol. 191, 152-159.

Mesquita, C.S., Oliveira, R., Bento, F., Geraldo, D., Rodrigues, J.V., Marcos, J.C., 2014. Simplified 2,4-dinitrophenylhydrazine spectrophotometric assay for quantification of carbonyls in oxidized proteins. Anal. Biochem. 458, 69-71.

Monchaux, D., Montigny, C., Reynouard, C., Guillemet, L., 2015. Etat initial environnemental dans la zone de l'agrandissement de I'U.P.G lié au programme Ariane 6. Hydreco-Guyana SARL / ANTEA, French Guiana, p. 33.

Nayak, P., 2002. Aluminium: impacts and disease. Environ. Res. 89, 101-115.

Neville, C., 1985. Physiological response of juvenile rainbow trout, Salmo gairdneri, to acid and aluminum-prediction of field responses from laboratory data. Can. J. Fish. Aquat. Sci. 42, 2004-2019.

Novais, S.C., Soares, A.M., De Coen, W., Amorim, M.J., 2013. Exposure of Enchytraeus albidus to $\mathrm{Cd}$ and $\mathrm{Zn}$-Changes in cellular energy allocation (CEA) and linkage to transcriptional, enzymatic and reproductive effects. Chemosphere 90, 1305-1309.

Oyanedel, D., González, R., Brokordt, K., Schmitt, P., Mercado, L., 2016. Insight into the messenger role of reactive oxygen intermediates in immunostimulated hemocytes from the scallop Argopecten purpuratus. Dev. Comp. Immunol. 65, 226-230.

Packard, T.T., 1974. The measurement of respiratory electron-transport activity in marine phytoplankton. J. Mar. Res. 29, 235-244.

Paglia, D.E., Valentine, W.N., 1967. Studies on the quantitative and qualitative characterization of erythrocyte glutathione peroxidase. J. Lab. Clin. Med. 70, 158-169.

Pan, T.-C.F., Applebaum, S.L., Manahan, D.T., 2015. Experimental ocean acidification alters the allocation of metabolic energy. Proc. Natl. Acad. Sci. 112, 4696-4701.

Peinado, J., Florindo, J., Garcia-Alfonso, C., Martinez-Galisteo, E., Llobell, A., Lopez-Barea, J., 1991. Metals are directly involved in the redox interconversion of Saccharomyces cerevisiae glutathione reductase. Mol. Cell. Biochem. 101, 175-187.

Peles, J.D., Pistole, D.H., Moffe, M., 2012. Influence of cadmium concentration and length of exposure on metabolic rate and gill $\mathrm{Na}^{+} / \mathrm{K}^{+}$ATPase activity of golden shiners (Notemigonus crysoleucas). Comp. Biochem. Physiol. C: Toxicol. Pharmacol. 156, 24-28.

Pörtner, H.O., Langenbuch, M., Reipschläger, A., 2004. Biological impact of elevated ocean $\mathrm{CO}_{2}$ concentrations: lessons from animal physiology and earth history. J. Oceanogr. 60, 705-718. Rajalekshmi, P., Mohandas, A., 1993. Effect of heavy metals on tissue glycogen levels in the freshwater mussel, Lamellidens corrianus (Lea). Sci. Total Environ. 134, 617-630.

Rejeki, S., 2003. Accumulation of aluminium in the tissue of giant fresh water prawn (Macrobrachium rosenbergii de Man) exposed to acidic water contaminated with aluminium salt. J. Coast. Dev. 6, 83-95.

Rendal, C., Kusk, K.O., Trapp, S., 2011. Optimal choice of pH for toxicity and bioaccumulation studies of ionizing organic chemicals. Environ. Toxicol. Chem. 30, 2395-2406.

Richard, S., Chemoul, B., 2012. Impact of launchers on the environment in French Guiana. In: Ouwehand, L. (Ed.). 5th IASS Conference: A safer space for a safer world. European Space Agency, Noordwijk, Netherlands.

Rosseland, B.O., Eldhuset, T.D., Staurnes, M., 1990. Environmental effects of aluminium. Environ. Geochem. Health 12, 17-27.

Sokolova, I., Frederich, M., Bagwe, R., Lannig, G., Sukhotin, A.A., 2012. Energy homeostasis as an integrative tool for assessing limits of environmental stress tolerance in aquatic invertebrates. Mar. Environ. Res. 79, 1-15. 
Solé, M., Rivera-Ingraham, G.A., Freitas, R., 2018. The use of carboxylesterases as biomarkers of pesticide exposure in bivalves: A methodological approach. Comp. Biochem. Physiol. C Comp. Pharmacol. 212, 18-24.

Stumpp, M., Wren, J., Melzner, F., Thorndyke, M.C., Dupont, S.T., 2011. CO2 induced seawater acification impacts sea urchin larval development I: elevated metabolic rates decrease scope for growth and induce developmental delay. Comp. Biochem. Physiol. A: Mol. Integr. Physiol. 160, 331-340.

Tang, P.-S., 1933. On the Rate of Oxygen Consumption by Tissues and Lower Organisms as a Function of Oxygen Tension. Q. Rev. Biol. 8, 260-274.

Thomsen, J., Melzner, F., 2010. Moderate seawater acidification does not elicit long-term metabolic depression in the blue mussel Mytilus edulis. Mar. Biol. 157, 2667-2676.

Vera-Silva, A.L., Lopes de Carvalho, F., Mantelatto, F.L.M., 2017. Redescription of the freshwater shrimp Macrobrachium jelskii (Miers, 1877) (Caridea, Palaemonidae). Zootaxa 4269, 44-60.

Voigt, C., Schumann, U., Graf, K., 2016. Contrail formation in the tropopause region caused by emissions from an Ariane 5 rocket. Progress in Propulsion Physics 8, 183-196.

Whiteley, N.M., 2011. Physiological and ecological responses of crustaceans to ocean acidification. Mar. Ecol. Prog. Ser. 430, 257-271.

Wood, H.L., Spicer, J.I., Widdicombe, S., 2008. Ocean acidification may increase calcification rates, but at a cost. Proc. R. Soc. Biol. Sci. Ser. B 275, 1767-1773.

Wu, Z., Du, Y., Zue, H., Wu, Y., Zhou, B., 2012. Aluminum induces neurodegeneration and its toxicity arises from increased iron accumulation and reactive species (ROS) production. Neurobiol. Aging 33, e1-a12. 
Are we neglecting Earth while conquering space? Effects of aluminized solid rocket fuel combustion on the physiology of a tropical freshwater invertebrate

Georgina A. Rivera-Ingraham ${ }^{1,4}$, Madalena Andrade ${ }^{2}$, Regis Vigouroux ${ }^{1}$, Montserrat Solé ${ }^{3}$, Katherina Brokordt ${ }^{4}$, Jehan-Hervé Lignot ${ }^{5}$, Rosa Freitas ${ }^{2}$

\section{HIGHLIGHTS}

- Propergol fuel releases $\mathrm{Al}_{2} \mathrm{O}_{3}$ and hydrochloric acid $(\mathrm{HCl})$ upon combustion.

- No physiological assessments on their impact have been carried out so far.

- Simultaneous exposure to these two compounds produces toxicity in tropical shrimps.

- The impact is mediated by respiration impairment and loss of acid-base regulation.

- Esterases and glutathione reductase activities are good indicators for this impact. 
Are we neglecting Earth while conquering space? Biomarkers for the effects of aluminized solid rocket fuel combustion on the physiology of a tropical freshwater invertebrate

Georgina A. Rivera-Ingraham ${ }^{1,4}$, Madalena Andrade ${ }^{2}$, Regis Vigouroux ${ }^{1}$, Montserrat Solé ${ }^{3}$, Katherina Brokordt $^{4}$, Jehan-Hervé Lignot ${ }^{5}$, Rosa Freitas ${ }^{2}$

\section{Declaration of interests}

$\bigotimes$ The authors declare that they have no known competing financial interests or personal relationships that could have appeared to influence the work reported in this paper.

$\square$ The authors declare the following financial interests/personal relationships which may be considered as potential competing interests: 